\title{
Effect of family centered empowerment model on hemodialysis patients and their caregivers
}

\author{
Omebrahiem A. El-Melegy, Amaal M. Al-Zeftawy, , Samia E. Khaton \\ Faculty of Nursing, Tanta University, Tanta, Egypt
}

Received: April 14, 2016

Accepted: June 21, 2016

Online Published: July 11, 2016

DOI: $10.5430 /$ jnep.v6n11p119

URL: http://dx.doi.org/10.5430/jnep.v6n11p119

\begin{abstract}
Background: Hemodialysis is a prolonged process that affects all life aspects of the patient and his family including the physiological, psychological, functional ability, and lifestyle changes. The aim of this study was as to evaluate the effect of family centered empowerment model on hemodialysis patients and their caregivers.

Methods: Quasi experimental design was used in this study. This study was conducted in dialysis unit in Tanta University Hospital. Fifty hemodialysis patients and fifty caregivers attending the previous setting were included in the study. Tools of the study: Five tools were used in this study; Pre-test data were obtained by using two socio-demographic data form for patients and caregivers and three questionnaires tools for self-efficacy and burden level. Empowerment intervention was given to the studied subjects then post test data was collected.

Results: The majority of the studied subjects obtained low score level of self-efficacy in relation to (autonomy, self integration, problem solving ability and seeking social support category) pre-empowerment intervention, while post empowerment, none of them fall in the same category and more than two thirds of them had high score regarding level of autonomy, level of self integration and problem solving ability. Most caregivers have low self efficacy pre empowerment. While post empowerment, more than two thirds and nearly one third of them fall in moderate and high level respectively. All caregivers obtained severe burden level pre empowerment while post empowerment $66 \%$ falls in mild to moderate level.

Conclusions and recommendation: Empowerment of hemodialysis patients and their caregivers can assist them with the management of health-related problems and improve their self efficacy and decrease the burden level of the caregivers so the study recommended that before the beginning of dialysis therapy, health professionals should identify and explore patient needs and potential caregiver in the family of patient and established empowerment programs to prepare them for the task to be carried out, mainly in the initial phase of their activities.
\end{abstract}

Key Words: Hemodialysis, Empowerment, Self-efficacy, Caregivers' burden

\section{INTRODUCTION}

End stage renal disease (ESRD) is a major public health problem, because of high morbidity and mortality as well as significant social and financial burden of this disease and its increasing prevalence. ${ }^{[1-3]}$ The incidence of ESRD in Egypt is growing and reached 79.9 patient/million population in the year 2001. The estimated number of ESRD patients in- creased to 35,751 in 2004. ${ }^{[4]}$ A significant shortage of renal donors all over the world makes the dialysis (hemodialysis) (HD) or peritoneal dialysis (PD) is the main route of treatment rather than renal transplantation. ${ }^{[5]} \mathrm{HD}$ is a process in which excess fluids and wastes are removed using a membrane instead of a kidney as a filter and isn't a cure. HD is a prolonged and expensive procedure that requires following a

*Correspondence: Amaal M. Al -Zeftawy; Email: amaal_alzeftawy@yahoo.com; Address: Faculty of Nursing, Tanta University, Tanta, Egypt. 
specific regimen of diet and fluid so it accompanies with life style changes. ${ }^{[6,7]}$ Further, physical and psychosocial stressors facing those patients involving lack of appetite, anemia, hypertension, sexual disorders, reduced income, social isolation, dependence on caregivers and loss of sense of security, etc. ${ }^{[8-10]}$

Hemodialysis session is usually takes hours three times a week. Hemodialysis process needs comprehensive and collaborative efforts from the whole health care team. The main core of the health care team is the patient and his family. If the patient has adequate knowledge regarding the management process, he can interact with his health care team to give himself the best outcomes, and reach to full, active life. ${ }^{[11]}$ Education, problem solving approach, and support are considered the most important empowering approaches that help HD patients and their caregivers to take a responsibility for managing disease associated problems or complications. ${ }^{[12,13]}$

Family caregivers of a patient with ESRD are anxious and frightening about their future. They also are feeling ashamed from their sense of anger, fatigue, and frustration and being perceived by others as bad or inadequate partners. Understanding disease-related changes among the affected person in the family may help them to feel secure about the future. Also it helps them to handle the situation within the family. ${ }^{[14]}$ It is difficult to live with an ESRD patient especially if we have lack of insight into the disease and lack of support from professionals. ${ }^{[15,16]}$

Undergoing dialysis process interrupts the entire of the family. So, family empowerment can decrease burden level through improving physical and mental function and increase self-ability. ${ }^{[13]}$ Family empowerment model is designed upon effectiveness of the individual and other family member's role on the three motivational, psychological (self-esteem, self-control and self-efficacy) and self-problem characteristics (like perceived knowledge, attitude and perceived threat). The main goal of family empowerment model is to strengthen the family (patient and other members) in order to improve the health level. The model of family centered empowerment consists of four steps including: First step: increasing knowledge level through educational sessions by using educational assistive materials such as power point, posters, model and handouts and educational methods as group discussion, question and answer and lecture. Second step: self-efficacy improvement; third step increasing self-esteem through educational participation; and fourth step including evaluation process during the empowerment sessions. ${ }^{[17]}$

Self-efficacy meaning that the person has a confidence in his or her ability to carry out actions and to be sustained in this actions despite of difficulties or challenges. ${ }^{[18,19]}$ Developing the perception of self-efficacy improving engaging in health-promoting behaviors, thinking style, motivation, and emotional wellness state. ${ }^{[20]}$ Furthermore, self-efficacy improvement can help the person to become more experienced and knowledgeable. This positive effect on perception can enhance adoption of proper behavior. Sources of self-efficacy include modeling through watching others' behaviors, mastery experiences, verbal persuasion from a significant person, and physiologic feedback. Using one or all of these self-efficacy sources through initiation and practice of selfmanagement tasks helps patients acquire sense of control over the disease process. ${ }^{[21]}$ Improving self-efficacy of HD patients and their caregivers has a positive effect on changing health status, compliance with prescribed regimens and interventions that improve disease outcomes. ${ }^{[22]}$

Family caregivers of hemodialysis patients are facing difficulties to control over their daily living activities and usually being afraid about their family member's condition and have a less chance to plan their own activities. ${ }^{[23]}$ Nurses have an essential role in increasing caregivers' confidence and hope which promotes family health and wellness. All family functions can be disturbed because of concerning about patient's health care needs, medical and educational services, cost of the disease, missing social opportunities, frequent absences from work and physical and psychological problems. So, participation of the patient in the care process alongside his/her family caregiver is very important. Dialysis management is considered an important objective burden associated with ESRD patient care. Since presence of caregiver is essential to take care of the patients on dialysis and helps them in conducting daily living activities. Objective caregiver burden includes tasks or burden needed to care for the patient, and subjective burden covers to what extent the caregiver carry out these tasks. ${ }^{[24]}$ So, the aim of the present study was to evaluate the outcome of empowerment as experienced by hemodialysis patients and their family caregivers on their self efficacy and burden level of caregivers.

\subsection{Aim of the study}

This study aims to evaluate the effect of family centered empowerment model on hemodialysis patients and their caregivers.

\subsection{Research hypothesis}

(1) Self-efficacy among hemodialysis patients will be improved after implementing the family center empowerment.

(2) Self-efficacy among caregivers of hemodialysis pa-

ISSN 1925-4040 E-ISSN 1925-4059 
tients will be improved after implementing the family center empowerment.

(3) Burden level on caregivers of hemodialysis patients will be minimized after implementing the family center empowerment.

\section{MATerials AND METHOD}

Quasi experimental study design was used. This study was conducted in dialysis unit in Tanta University Hospital. Fifty Hemodialysis patients and fifty of their caregivers who attended the previous setting for dialysis in the morning and afternoon shifts were included in the study. Eligibility criteria included the following: subjects diagnosed with ESRD and treated with HD for at least one year, patients who lived at home and comes for hemodialysis (not hospitalized), had no cognitive or psychiatric disorders and willing to participate in the study. Those who were hospitalized or have acute illnesses were excluded.

Duration of the study: all the stages of the study, from the pre assessment until ending the implementation and evaluation phase, takes about three months from the start of January till the end of March 2015.

\subsection{Tools of the study}

Five tools were used in this study; two tools for patients and three tools for caregivers.

Patients tools included:

\section{Tool I}

Structured interview questionnaire sheet consisted of two parts; part 1, socio demographic data and part 2, clinical data such as causes and duration of renal failure of the disease, time of starting dialysis and medication taken.

\section{Tool II}

Chronic Kidney Disease Self-Efficacy Instrument (CKD$S E)^{[25]}$ In this instrument, self-efficacy was measured by a 25-item self-reported questionnaire. Total self-efficacy was scored by summing the responses of the individual items in five Likert scale. Dimensions for CKD-SE instrument include:

Autonomy consisted of eight items covers patients' confidence to express their own concerns or questions about disease process and treatment freely and comfortably; 8 items with score range (8-40).

Self-integration reflected patients' confidence in adjusting their lifestyle and implementing recommended regimens and self-care activities in order to achieve a balanced life; 7 items with score range (7-35).

Published by Sciedu Press
Problem solving related to CKD six items reflected the patients' confidence to learn disease-specific information to achieve better disease control; 6 items with score range (6$30)$.

Seeking social support four items focused on patients' confidence in seeking support from significant others to cope with their disease; 4 items with score range (4-20). The possible score for overall self efficacy were 25-125. Higher scores reflected better outcomes. The levels of each category and the overall self efficacy were categorized as Low $(<60 \%$ of total score); Moderate ( $60 \%<80 \%$ of total score); High $(\geq$ $80 \%$ of total score).

Caregivers Tools:

\section{Tool I}

Structured interview questionnaire sheet used to assess socio demographic data of the caregiver and the duration that he or she offering care to the patient.

\section{Tool II}

Revised scale of Caregiver Self efficacy (Steffen et al., 2002): ${ }^{[26]}$ This scale developed by Steffen et al. (2002) measuring three dimensions (categories) of caregivers' self efficacy: Self efficacy for obtaining respite, self efficacy for controlling upsetting thoughts about care giving and self efficacy for responding to disruptive patient behaviors. In this scale, caregiver told how confident that he or she could do each item and asked to rate his or her degree of confidence using any score between 0 and $100(10,20,30$, etc.). Only ten questions which cover the two categories of self efficacy for obtaining respite and self efficacy for controlling upsetting thoughts about care giving were taken in this study. Questions that cover the third category related to self efficacy for responding to disruptive patient behaviors were not taken in this study, as they not applicable to our patients.

\section{Tool III}

Caregiver Burden Interview ${ }^{[27,28]}$ This instrument consisted of a 22 items; it was completed by caregivers as a measure of subjective response to care giving such as feeling stressed, embarrassed, angry, strained and suffered because of involvement with his relative care, afraid about what the future holds for his relative, worry about effect on social life, relationships and economic condition, afraid about inability to take care of him more and lost control of his life since his relative's death.

The burden interview was scored by summing the responses of the individual items in five point Likert scale. Higher scores indicated greater caregiver distress.

$=(0-20) \rightarrow$ No burden to little 
$=(21-40) \rightarrow$ Mild to moderate burden

$=(41-60) \rightarrow$ Moderate to severe burden

$=(61-88) \rightarrow$ Severe burden

\section{METHOD}

- Before starting the study, an official letter was addressed from the dean of the faculty of nursing to the director of dialysis unit to request his permission and cooperation to collect data from the selected setting.

- The tools of the study were translated by the researchers to Arabic language and were validated by a jury to ensure the content validity of the translated version by original one. The jury consisted of seven experts in the community health and medical surgical nursing fields. The required correction and modifications were carried out accordingly.

- Patients were interviewed at dialysis unit as a part of their routine HD and caregivers were interviewed in waiting area and sometimes in the dialysis unit beside the patients.

- For ethical consideration; Informed consent was obtained from the study subject (patients and caregivers) to participate in the study after explanation the purpose of the study and assurance the subjects about their privacy and confidentiality of the obtained data. The study subjects were informed that they have a right to withdraw from the study at any time if they wanted.

- Empowerment intervention was implemented by the researchers.

- The general objective of the empowerment intervention was to support patients and caregivers selfconfidence, informing them regarding the disease and its limitations, empowering them against stressful situations and acquiring them with proper problem solving technique in order to improve patients' self care self efficacy and caregivers' self efficacy and burden level.

- General principles stated in this empowering intervention were educating, ensuring, guidance, empathy, encouragement and the chance to express emotions to promote social support from others.

- The subjects were classified in two small groups in order to facilitate the empowerment process, ( 9 groups of patients and 9 groups of caregivers), according to their dialysis schedule. Each group of patients or caregivers contain from 5-6 individual.

- Empowerment intervention was performed in 6 sessions twice weekly for each group of patients and caregivers. Duration of each session ranged from 1-1.5 hours. Individual sessions were conducted sometimes according to needs and situation.

- Before conducted the sessions, subjects were evaluated by three different assessment forms, Self Efficacy Instrument for Hemodialysis patients and Self Efficacy care giver Revised Scale and caregivers Burden Interview to identify self care problems and identify their educational needs.

- The sessions starting by introducing group members followed by the familiarization phase aimed at an accurate diagnosis of problems with HD care, motivating the clients and determining their needs for the care process. The researchers coordinated a meeting which lasted 15-30 minutes during which the patient and his/her caregiver were familiarized with the empowerment process, briefed on mutual expectations and advised to be cooperated with the researchers.

- The participants took part in counseling sessions, group discussions, presentations and question-andanswer sessions about the nature and diversity of needs and problems facing the HD patient and his/her family to diagnose new problems, and to sensitize and motivate the participants to persevere with the process.

- The sessions focused also on managing stress, motivation, social support and coping strategies which are problem and emotion-focused. Group discussion/reflection based on life experiences of the participants and question and answer techniques were used for making them aware of problem solving techniques and coping strategies of their own and others.

- Muscle relaxation exercise was practiced in the caregivers as possible as a method for stress management.

- Participants were contacted by phone to facilitate their continuous involvement in the intervention.

- Group discussions, question-and-answer and demonstration for caring of dialysis site were used as teaching methods. Real objects, flip charts, power point and pictures were used as teaching aids.

\section{Evaluation of the intervention}

Two assessments were done to the participants in order to assess their self efficacy and burden level of caregivers.

- First time: Before implementation of the empowerment intervention, (using the five study Tools).

- Second time: After the implementation of the empowerment intervention plan by 6 weeks, (Using Tool II for the patient \& Tool II and Tool III) for caregivers.

\section{Statistical analysis}

The data were coded, entered and analyzed using SPSS (version 20). Descriptive statistics (frequency numbers and per- 
centages) identified demographic characteristics and subjects responses to the questionnaire. Chi-square test analyzes the differences and a significant difference was set at $P$ value $<$ $.05 \%$.

\section{Results}

\subsection{Patients' results}

Table 1 represents the distribution of the studied subjects by their socio-demographic characteristics. It shows that, the age of the studied subjects ranged from 18-65 years, with a mean $47.18 \pm 14.24$ years. More than half of participant subjects $(54 \%)$ were male. About two thirds (64\%) of the subjects were married. Nearly half (48\%) of them had secondary education and $40 \%$ of them were illiterate. Only one third $(34 \%)$ of subjects were worked while nearly half of them $(48 \%)$ did not work.

Table 1. Socio-Demographic characteristics of the studied patient

\begin{tabular}{lll}
\hline Socio Demographic Characteristics & No & $\%$ \\
\hline Age & 9 & 18.0 \\
18-40 years & 31 & 62.0 \\
41-60 years & 10 & 20.0 \\
> 60 years & & \\
Range 18-65 Mean \pm SD 47.18 \pm 14.24 & & \\
Sex & 27 & 54.0 \\
Male & 23 & 46.0 \\
Female & & \\
Marital Status & 32 & 64.0 \\
Married & 9 & 18.0 \\
Single & 9 & 18.0 \\
Widow & & \\
Education & 20 & 40.0 \\
Illiterate \&read and write & 24 & 48.0 \\
Secondary education & 6 & 12.0 \\
University education & & \\
Occupation & 17 & 34.0 \\
Work & 5 & 10.0 \\
Retired & 24 & 48.0 \\
Do not work & 4 & 8.0 \\
Student & & \\
\hline
\end{tabular}

Table 2 represents the distribution of the studied subjects by their medical history. More than one half (60\%) of the subjects reported that the cause of their disease was chronic renal inflammations followed by $20 \%$ of them related to congenital renal deficits, $12 \%$ related to diabetic and $8 \%$ related to hypertension. Nearly one half (46\%) of patients had renal failure for a duration ranged from 10-15 years ago and more than one third (36\%) of them from 6-9 years with a mean duration $8.8200 \pm 3.61793$. Slightly less than half (42\%) of subjects started dialysis since 6-9 years ago with a mean duration $7.5200 \pm 3.01181$.
Table 3 represented score of self efficacy categories pre and post empowerment intervention among studied patients. In relation to level of, the majority (98\% and $100 \%)$ respectively of the subjects obtained low level pre-empowerment, while post empowerment, none of the subjects fell in the same category and $76 \%$ of them had high level. A statistically significant relation was obtained between levels of autonomy, problem solving ability and self-integration pre and post empowerment intervention $(P<.05)$.

As regard seeking social support category, study result shows also that, the majority of the studied subjects (98\%) had low ability for seeking social support pre-empowerment. while $90 \%$ of the subjects obtained high ability for seeking social support after empowerment intervention with a statistically significant difference at level of $(P<.05)$.

Moreover, the study result shows also that there was a statistically significant difference $(P<.05)$ between total score of subjects' self efficacy pre and post empowerment intervention. All of the patients found to have low self efficacy pre empowerment. While, post empowerment nearly half (42\%) and more than half $(58 \%)$ of them fell in moderate and high level respectively (see Figure 1).

Table 2. Distribution of the studied patients by their medical history

\begin{tabular}{|c|c|c|}
\hline Medical history & No & $\%$ \\
\hline \multicolumn{3}{|l|}{ Causes of renal failure } \\
\hline Diabetic & 6 & 12.0 \\
\hline Hypertension & 4 & 8.0 \\
\hline Chronic renal inflammation & 30 & 60.0 \\
\hline Congenital renal defect & 10 & 20.0 \\
\hline \multicolumn{3}{|l|}{ Duration of disease } \\
\hline $2-5$ years & 9 & 18 \\
\hline $6-9$ years & 18 & 36 \\
\hline 10-15 years & 23 & 46 \\
\hline \multicolumn{3}{|c|}{ Range 2-15 Mean \pm SD $8.8200 \pm 3.61793$} \\
\hline \multicolumn{3}{|l|}{ Starting dialysis } \\
\hline $2-5$ years & 14 & 28 \\
\hline $6-9$ years & 21 & 42 \\
\hline $10-15$ years & 15 & 30 \\
\hline \multicolumn{3}{|c|}{ Range 2-15 Mean \pm SD $7.5200 \pm 3.01181$} \\
\hline \multicolumn{3}{|c|}{ Taking medication with dialysis } \\
\hline Yes & 50 & 100.0 \\
\hline \multicolumn{3}{|l|}{ Presence of other complain } \\
\hline Yes & 17 & 34.0 \\
\hline No & 33 & 66.0 \\
\hline \multicolumn{3}{|c|}{ If yes (disease or complain) $(\mathrm{N}=17)$} \\
\hline Diabetic & 6 & 35.3 \\
\hline Heart disease & 2 & 11.8 \\
\hline Peptic ulcer & 1 & 5.9 \\
\hline Liver disease & 4 & 23.5 \\
\hline
\end{tabular}


Table 3. Comparison between score of self efficacy categories pre and post empowerment among studied patients

\begin{tabular}{|c|c|c|c|c|c|c|c|}
\hline \multirow{2}{*}{ Categories } & & \multicolumn{2}{|c|}{ Pre $(n=50)$} & \multicolumn{2}{|c|}{ Post $(n=50)$} & \multirow{2}{*}{$\chi^{2}$} & \multirow{2}{*}{$P$} \\
\hline & & $\mathbf{N}$ & $\%$ & $\mathbf{N}$ & $\%$ & & \\
\hline \multirow{3}{*}{ Autonomy } & Low & 49 & 98 & 0 & 0 & \multirow{3}{*}{96.308} & \multirow{3}{*}{$.001^{*}$} \\
\hline & Moderate & 1 & 2 & 12 & 24 & & \\
\hline & High & 0 & 0 & 38 & 76 & & \\
\hline \multirow{3}{*}{ Self-integration } & Low & 50 & 100 & 0 & 0 & \multirow{3}{*}{100} & \multirow{3}{*}{$.001^{*}$} \\
\hline & Moderate & 0 & 0 & 38 & 76 & & \\
\hline & High & 0 & 0 & 12 & 24 & & \\
\hline \multirow{3}{*}{ Problem solving } & Low & 49 & 98 & 1 & 2 & \multirow{3}{*}{92.444} & \multirow{3}{*}{$.001^{*}$} \\
\hline & Moderate & 1 & 2 & 10 & 20 & & \\
\hline & High & 0 & 0 & 39 & 78 & & \\
\hline \multirow{3}{*}{ Seeking social support } & Low & 49 & 98 & 0 & 0 & \multirow{3}{*}{96.667} & \multirow{3}{*}{$.001^{*}$} \\
\hline & Moderate & 1 & 2 & 5 & 10 & & \\
\hline & High & 0 & 0 & 45 & 90 & & \\
\hline \multirow{3}{*}{ Total self-efficacy score } & Low & 50 & 100 & 0 & 0 & \multirow{3}{*}{100} & \multirow{3}{*}{$.001 *$} \\
\hline & Moderate & 0 & 0 & 21 & 42 & & \\
\hline & High & 0 & 0 & 29 & 58 & & \\
\hline
\end{tabular}

* Significant at $P<.05$

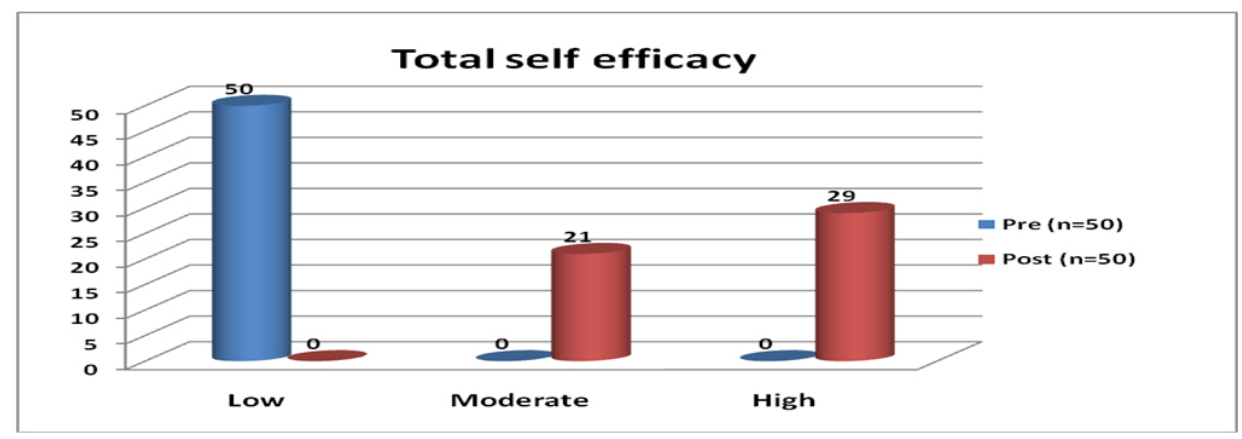

Figure 1. Comparison between total self efficacy score pre and post empowerment among studied patients

Table 4 represents the relation between socio demographic data and total self efficacy score among studied subjects post empowerment. The table shows that, there was no statistically significant difference found between patients' total self-efficacy and their age, sex, education and occupation post empowerment.

Table 5 represents the distribution of the studied caregivers by their socio-demographic characteristics. It shows that, the age of the studied caregivers ranged from 30-65 years, with a mean $43.18 \pm 8.60$ years. More than three quarters $(76 \%)$ of participant caregivers were female and the majority (94\%) of them was married. Nearly half (46\%) of the caregivers had secondary education and $34 \%$ of them were illiterate or read and write. One third (32\%) of caregivers were worked while two thirds of them (68\%) did not work. $60 \%$ of caregivers reported that their family income was sufficient compared to
$40 \%$ of them had insufficient family income.

As regards the caregivers' relation degree to the patients, more than half (56\%) of care givers were their wives and about one quarter (25\% and $20 \%$ ) were their sons or daughters and their fathers or mothers respectively. The table shows that the period in which caregivers responsible for patient care and companionship ranged from 2-10 years with a mean $6.26 \pm 2.32$. More than two thirds $(71.42 \%)$ of them and more than one quarter $(28 \%)$ of those caregivers themselves had hypertension and diabetic.

Table 6 represents the differences in the total scores of caregivers' self-efficacy categories in response to empowerment intervention. In relation to level of total respect score and self-control ability, the majority ( $88 \%$ and $90 \%$ ) respectively of caregivers fell in low level pre-empowerment. While post 
empowerment, none of the subjects fell in the same category obtain high score with statistically significant difference at and $72 \%$ of them had moderate level of total respect and $28 \%$ level of $(P<.05)$ (see Figure 2$)$.

Table 4. Relation between socio demographic data and total self efficacy score among studied patients post empowerment

\begin{tabular}{|c|c|c|c|c|c|c|c|c|c|}
\hline \multirow{3}{*}{ Categories } & & \multicolumn{3}{|c|}{ Pre $(n=50)$} & \multicolumn{5}{|c|}{ Post $(n=50)$} \\
\hline & & \multicolumn{2}{|c|}{ Low $<75$} & \multirow{2}{*}{$\begin{array}{l}\chi^{2} \\
P\end{array}$} & \multicolumn{2}{|c|}{ Moderate 75-99 } & \multicolumn{2}{|c|}{ High $\geq 100$} & \multirow{2}{*}{$\begin{array}{l}\chi^{2} \\
P\end{array}$} \\
\hline & & $\mathbf{N}$ & $\%$ & & $\mathbf{N}$ & $\%$ & $\mathbf{N}$ & $\%$ & \\
\hline \multirow{3}{*}{ Age } & $18-40$ years $(n=9)$ & 9 & 18 & \multirow{3}{*}{-} & 5 & 10 & 4 & 8 & \multirow{3}{*}{$\begin{array}{l}8.33 \\
.659\end{array}$} \\
\hline & $41-60$ years $(n=31)$ & 31 & 62 & & 12 & 24 & 19 & 38 & \\
\hline & $>60$ years $(n=10)$ & 10 & 20 & & 4 & 8 & 6 & 12 & \\
\hline \multirow{2}{*}{ Sex } & Male $(n=27)$ & 27 & 54 & \multirow{2}{*}{ - } & 9 & 18 & 18 & 36 & \multirow{2}{*}{$\begin{array}{l}1.810 \\
.179\end{array}$} \\
\hline & Female $(n=23)$ & 23 & 46 & & 12 & 24 & 11 & 22 & \\
\hline \multirow{3}{*}{ Marital status } & Married (n = 32) & 32 & 64 & \multirow{3}{*}{-} & 10 & 20 & 22 & 44 & \multirow{3}{*}{$\begin{array}{l}4.445 \\
.108\end{array}$} \\
\hline & Single $(n=9)$ & 9 & 18 & & 5 & 10 & 4 & 8 & \\
\hline & Widow $(n=9)$ & 9 & 18 & & 6 & 12 & 3 & 6 & \\
\hline \multirow{3}{*}{ Education } & Illiterate, read and write $(\mathrm{n}=20)$ & 20 & 40 & \multirow{3}{*}{-} & 9 & 18 & 11 & 22 & \multirow{3}{*}{$\begin{array}{l}0.260 \\
.878\end{array}$} \\
\hline & Secondary education $(n=24)$ & 24 & 48 & & 10 & 20 & 14 & 28 & \\
\hline & University education $(n=6)$ & 6 & 12 & & 2 & 4 & 4 & 8 & \\
\hline \multirow{4}{*}{ Occupation } & Work $(\mathrm{n}=17)$ & 17 & 34 & \multirow{4}{*}{-} & 5 & 10 & 12 & 24 & \multirow{4}{*}{$\begin{array}{l}3.047 \\
.384\end{array}$} \\
\hline & Retired $(n=5)$ & 5 & 10 & & 2 & 4 & 3 & 6 & \\
\hline & Do not work $(n=24)$ & 24 & 48 & & 11 & 22 & 13 & 26 & \\
\hline & Student $(n=4)$ & 4 & 8 & & 3 & 6 & 1 & 2 & \\
\hline
\end{tabular}

The study result shows that there was a statistically significant difference $(P<.001)$ between total score of caregivers self efficacy pre and post empowerment intervention. Most of caregivers (94\%) found to have low self efficacy pre empowerment. While post empowerment $70 \%$ and $30 \%$ of them fall in moderate and high level respectively.

Table 7 reveals caregivers' burden level pre and post empowerment intervention and differences in the total burden score. In relation to level of burden, all caregivers (100\%) obtained sever burden level pre empowerment intervention while post empowerment, none of the caregivers fell in the same category, $8 \%$ fell in moderate to severe level, $66 \%$ fell in mild to moderate level and $26 \%$ of them fell in little or no burden. There was a statistically significant difference $(P<$ .001) was obtained between the total mean score of burden level pre and post empowerment intervention with a mean difference $46.28 \pm 9.05$ (see Figure 3).

Table 8 shows the relation between socio demographic data and total self efficacy score among studied care givers. There was a significance difference found between caregivers self efficacy and their marital status, their relation degree to the patient pre empowerment and their education and occupation post empowerment $(P<.05)$. The table shows also that, there was no statistically significant difference found between care-

Published by Sciedu Press givers' total self-efficacy and their age and sex pre or post empowerment.

Table 9 represents the relation between socio demographic data and total burden level score among studied care givers. There was a significance difference found between caregiver's burden level and their relation degree to the patient, their educational level and the duration of responsibility for patient care \& companionship post empowerment $(P<.05)$. While, there was no statistically significant difference found between caregivers' total burden level and their age, sex and their marital status post empowerment.

\section{Discussion}

The patient and his family are considered the most important members of the care team. Self-efficacy of hemodialysis patients and their caregivers are important determinates of the of healthcare management outcome, nursing intervention and family empowerment. Empowering patients and caregivers during the care process may have a positive effect on relieving associated burden and self-care self-efficacy. ${ }^{[29,30]}$ So, the aim of the present study was to evaluate the effect of family-centered empowerment model on self-efficacy of both patients and their caregivers and also its effect on the caregivers' burden level. 
Table 5. Socio Demographic Characteristics of caregivers

\begin{tabular}{|c|c|c|}
\hline Socio Demographic Characteristics & No & $\%$ \\
\hline \multicolumn{3}{|l|}{ Age } \\
\hline $30-40$ years & 26 & 52.0 \\
\hline 41-65 years & 24 & 48.0 \\
\hline \multicolumn{3}{|l|}{ Range 30-65 Mean \pm SD $43.18 \pm 8.60$} \\
\hline \multicolumn{3}{|l|}{ Sex } \\
\hline Male & 12 & 24.0 \\
\hline Female & 38 & 76.0 \\
\hline \multicolumn{3}{|l|}{ Marital Status } \\
\hline Married & 47 & 94.0 \\
\hline Widow & 3 & 6.0 \\
\hline \multicolumn{3}{|l|}{ Relation degree to patient } \\
\hline Wife \& husband & 28 & 56.0 \\
\hline Son \& daughter & 12 & 24.0 \\
\hline Mother \& father & 10 & 20.0 \\
\hline \multicolumn{3}{|l|}{ Education } \\
\hline Illiterate \&read and write & 17 & 34.0 \\
\hline Secondary education & 23 & 46.0 \\
\hline University education & 10 & 20.0 \\
\hline \multicolumn{3}{|l|}{ Occupation } \\
\hline Work & 16 & 32.0 \\
\hline Not work & 34 & 68.0 \\
\hline \multicolumn{3}{|l|}{ Family income } \\
\hline Sufficient & 30 & 60.0 \\
\hline Not sufficient & 20 & 40.0 \\
\hline \multicolumn{3}{|c|}{$\begin{array}{l}\text { Duration of responsibility for patient care and } \\
\text { companionship }\end{array}$} \\
\hline $2-5$ years & 16 & 32.0 \\
\hline $6-10$ years & 34 & 68.0 \\
\hline \multicolumn{3}{|c|}{ Range 2-10 years Mean \pm SD $6.26 \pm 2.32$} \\
\hline \multicolumn{3}{|l|}{ Presence of complain or disease } \\
\hline Yes & 14 & 28.0 \\
\hline No & 36 & 72.0 \\
\hline If yes (disease) & $\mathrm{N}=(14)$ & \\
\hline Hypertension & 10 & 71.42 \\
\hline Diabetic & 4 & 28.58 \\
\hline
\end{tabular}

The age of nearly two thirds of the studied subjects were from 40 to 60 years and this agree with Jeffery 2015 who emphasized that the mean age of the patient undergoing dialysis in the United States has been steadily increasingly over the last decades. ${ }^{[31]}$ Older patients are now the rule rather than the exception in HD, with the median age at dialysis initiation at $64.4 \mathrm{yr}$ old. Furthermore, the older adults people are the fastest-growing age group of incident dialysis patients, meaning that this median age will persistent to increase. ${ }^{[32,33]}$

The current study reported the chronic renal inflammations as a main cause of renal failure followed by congenital renal deficits, diabetic and hypertension and slightly less than half of our patients starting dialysis since 6-9 years. Whereas,
Rayyani et al. (2014) found that hypertension is the underlying cause for the majority of his study's subjects and about two thirds of patients lived with ESRD for 1 to 5 years and had received hemodialysis. ${ }^{[34]}$ These results were in accordance to the results of Al-Garini (2006) and El-Sayed (2007) who found that the common underlying disease was hypertension, diabetes mellitus, followed by cardiovascular disorders. ${ }^{[35,36]}$

Enhancement of self-care efficacy level increase positively the self-care practice of the person. ${ }^{[37]}$ The present study reported a significant improvement in all self-efficacy categories for the majority of the studied subjects post empowerment intervention. This improvement of self-efficacy can be characterized the features of our empowerment program such as the provision of patient support for problem solving and participation of family members and health care givers in the problem solving process. Furthermore, patient engagement in the sessions during the study intervention improves their self- integration. This result agree with Moattari et al. (2012) who emphasized that a combination of individual and group empowerment counseling sessions improves self-efficacy in hemodialysis patients. Also, Masoodar et al. (2014) stated that empowerment based on educational needs for the studied subjects improves their attitudes toward disease, behavioral signs and intervention in low - economic safe and effective method. ${ }^{[12]}$ Royani et al. (2013) supported the important and effectiveness of the empowerment model to promote empowerment level and self-care self-efficacy of hemodialysis patients. ${ }^{[38]}$

The present study reported no significant difference found between patients' total score of self efficacy and their age which agreement with Berns (2010) and Weng et al. (2010) who found that, the correlation between patients' age and his self-care self-efficacy is negative. ${ }^{[39,40]}$

The current study showed that age of the study's caregivers ranged from 30-65 years, more than three quarters of them were female, two thirds of them did not work, more than half of them were patients' wives and one quarter were sons or daughters. These findings were in agreement with Belasco and Sesso (2002), Belasco et al. (2006) and Arechabala et al. (2011) who reported that caregivers of elderly dialysis patients basically were women, married, wives and sons or daughters, without remunerated jobs with a mean age of 46 years, and with low socioeconomic level. ${ }^{[24,41,42]}$

The present study reported a significant improvement in all self-efficacy categories for the majority of the studied caregivers post empowerment intervention. This results was emphasized also by Józef (2010) who stated that familycentered empowerment model is very important, because 
through empowerment programs the information and knowl- uals' skills, and knowledge of the society. Family-centered edge which are the best indicators of progress of a society, care programs will be able to play an essential role in the may be passed on to the next generation. Community educa- management of physical and mental health of patients by emtion, especially community empowerment which is consid- powering patients' families and improving their adherence ered a national investment, is expected to increase individ- to the therapeutic regimens. ${ }^{[43]}$

Table 6. Comparison between score of self efficacy categories pre and post empowerment among studied care givers

\begin{tabular}{|c|c|c|c|c|c|c|}
\hline \multirow{2}{*}{ Items } & & \multicolumn{2}{|c|}{ Pre $(n=50)$} & \multicolumn{2}{|c|}{ Post $(n=50)$} & \multirow{2}{*}{$\begin{array}{l}\chi^{2} \\
P\end{array}$} \\
\hline & & $\mathbf{N}$ & $\%$ & $\mathbf{N}$ & $\%$ & \\
\hline \multirow{3}{*}{ Self-Efficacy for Obtaining Respite } & Low & 44 & 88 & 0 & 0 & \multirow{3}{*}{$\begin{array}{l}79.429 \\
.001 *\end{array}$} \\
\hline & Moderate & 6 & 12 & 36 & 72 & \\
\hline & High & 0 & 0 & 14 & 28 & \\
\hline \multirow{3}{*}{ Self-Efficacy for Controlling Upsetting Thoughts about Care giving } & Low & 45 & 90 & 0 & 0 & \multirow{3}{*}{$\begin{array}{l}82.439 \\
.001 *\end{array}$} \\
\hline & Moderate & 5 & 10 & 36 & 72 & \\
\hline & High & 0 & 0 & 14 & 28 & \\
\hline \multirow{3}{*}{ Total self-efficacy } & 50 Low & 47 & 94 & 0 & 0 & \multirow{3}{*}{$\begin{array}{l}88.682 \\
.001 *\end{array}$} \\
\hline & Moderate & 2 & 4 & 35 & 70 & \\
\hline & High & 1 & 2 & 15 & 30 & \\
\hline
\end{tabular}

* Significant at $P<.05$

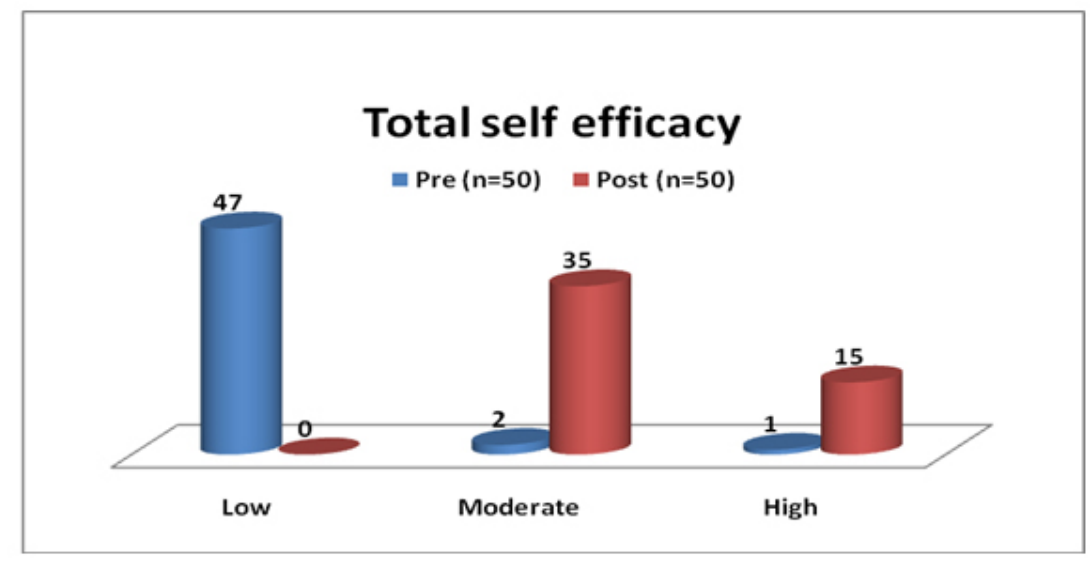

Figure 2. Total self-efficacy score pre and post empowerment among studied care givers

Table 7. Caregivers burden level pre and post empowerment intervention and differences in the total burden score

\begin{tabular}{|c|c|c|c|c|c|}
\hline \multirow{2}{*}{ Burden level } & \multicolumn{2}{|c|}{ Pre empowerment } & \multicolumn{2}{|c|}{ Post empowerment } & \multirow{2}{*}{$\begin{array}{l}\chi^{2} \\
P\end{array}$} \\
\hline & $\mathbf{N}$ & $\%$ & $\mathbf{N}$ & $\%$ & \\
\hline Little or no burden $(0-20)$ & 0 & 0 & 13 & 26.0 & \\
\hline Mild to moderate burden (21-40) & 0 & 0 & 33 & 66.0 & \\
\hline Moderate to severe burden (41-60) & 0 & 0 & 4 & 8.0 & \\
\hline Severe burden (61-88) & 50 & 100.0 & 0 & 0 & \\
\hline Range & \multicolumn{2}{|c|}{$63-88$} & \multicolumn{2}{|c|}{$18-47$} & \\
\hline Mean \pm SD & \multicolumn{2}{|c|}{$72.34 \pm 7.86$} & \multicolumn{2}{|c|}{$27.06 \pm 7.26$} & $<.001^{*}$ \\
\hline Median & \multicolumn{2}{|l|}{71} & \multicolumn{2}{|l|}{24} & \\
\hline Mean Difference & \multicolumn{2}{|c|}{$46.28 \pm 9.05$} & & & \\
\hline$t$-test & \multicolumn{2}{|c|}{36.12} & & & \\
\hline$P$ & \multicolumn{2}{|c|}{$<.001 *$} & & & \\
\hline
\end{tabular}




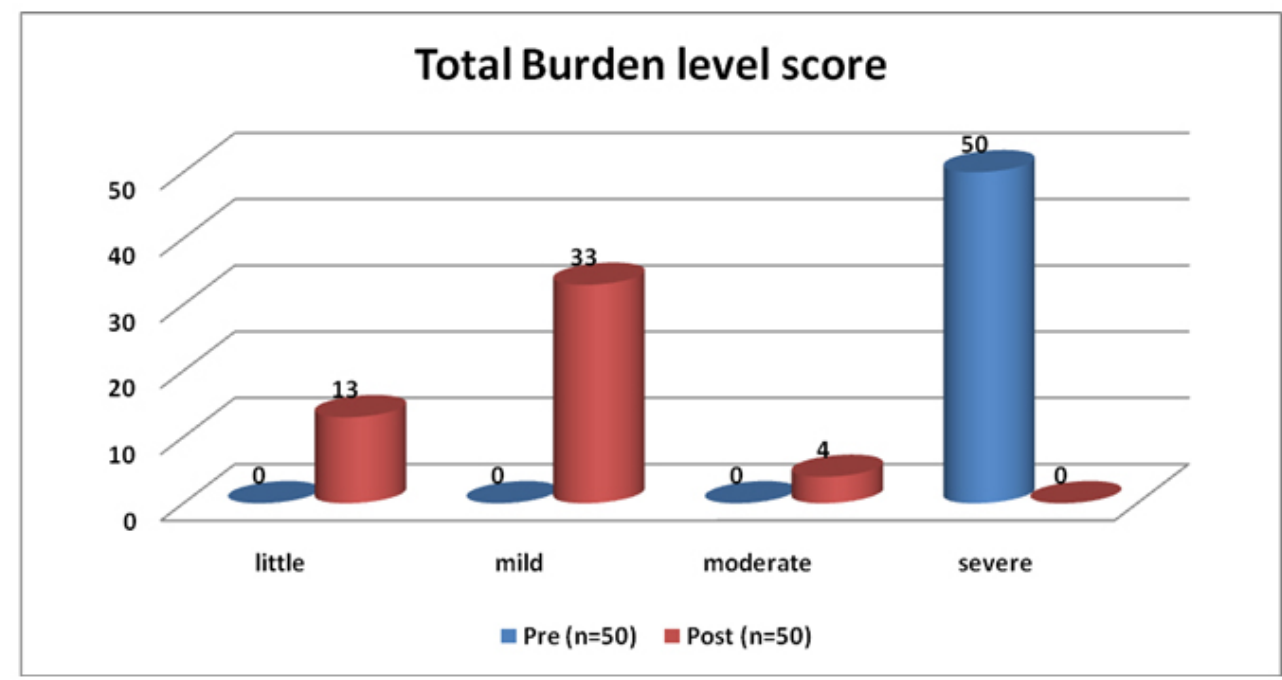

Figure 3. Caregivers burden level pre and post empowerment intervention

Table 8. Relation between socio demographic data and total self efficacy score among studied care givers

\begin{tabular}{|c|c|c|c|c|c|c|c|c|c|c|c|c|c|}
\hline \multirow{3}{*}{ Categories } & & \multicolumn{7}{|c|}{ Pre $(n=50)$} & \multicolumn{5}{|c|}{ Post $(n=50)$} \\
\hline & & \multicolumn{2}{|c|}{$\begin{array}{l}\leq \mathbf{5 0} \\
\text { Low }\end{array}$} & \multicolumn{2}{|c|}{$\begin{array}{l}51-74 \\
\text { Moderate }\end{array}$} & \multicolumn{2}{|c|}{$\begin{array}{l}\geq 75 \\
\text { High }\end{array}$} & \multirow{2}{*}{$\begin{array}{l}\chi^{2} \\
P\end{array}$} & \multicolumn{2}{|c|}{$\begin{array}{l}\text { 51-74 } \\
\text { Moderate }\end{array}$} & \multicolumn{2}{|c|}{$\begin{array}{l}\geq 75 \\
\text { High } \\
\end{array}$} & \multirow{2}{*}{$\begin{array}{l}\chi^{2} \\
P\end{array}$} \\
\hline & & $\mathbf{N}$ & $\%$ & $\mathbf{N}$ & $\%$ & $\mathbf{N}$ & $\%$ & & $\mathbf{N}$ & $\%$ & $\mathbf{N}$ & $\%$ & \\
\hline \multirow{2}{*}{ Age } & $30-40$ years & 25 & 50 & 0 & 0 & 1 & 2 & \multirow{2}{*}{$\begin{array}{l}3.116 \\
.211\end{array}$} & 16 & 32 & 10 & 20 & \multirow{2}{*}{$\begin{array}{l}1.847 \\
.174\end{array}$} \\
\hline & 41-65 years & 22 & 44 & 2 & 4 & 0 & 0 & & 19 & 38 & 5 & 10 & \\
\hline \multirow{2}{*}{ Sex } & Male & 11 & 22 & 0 & 0 & 1 & 2 & \multirow{2}{*}{$\begin{array}{l}3.807 \\
.149\end{array}$} & 7 & 14 & 5 & 10 & \multirow{2}{*}{$\begin{array}{l}1.023 \\
.312\end{array}$} \\
\hline & Female & 36 & 72 & 2 & 4 & 0 & 0 & & 28 & 56 & 10 & 20 & \\
\hline \multirow{2}{*}{ Marital status } & Married & 46 & 92 & 0 & 0 & 1 & 2 & \multirow{2}{*}{$\begin{array}{l}32.647 \\
.001^{*}\end{array}$} & 33 & 66 & 14 & 28 & \multirow{2}{*}{$\begin{array}{l}0.017 \\
.897\end{array}$} \\
\hline & Widow & 1 & 2 & 2 & 4 & 0 & 0 & & 2 & 4 & 1 & 2 & \\
\hline \multirow{3}{*}{$\begin{array}{l}\text { Relation degree } \\
\text { to patient }\end{array}$} & Wife & 28 & 56 & 0 & 0 & 0 & 0 & \multirow{3}{*}{$\begin{array}{l}11.489 \\
.02 *\end{array}$} & 21 & 42 & 7 & 14 & \multirow{3}{*}{$\begin{array}{l}1.111 \\
.574\end{array}$} \\
\hline & Son/daughter & 11 & 22 & 0 & 0 & 1 & 2 & & 7 & 14 & 5 & 10 & \\
\hline & Mother/father & 8 & 16 & 2 & 4 & 0 & 0 & & 7 & 14 & 3 & 6 & \\
\hline \multirow{3}{*}{$\begin{array}{l}\text { Level of } \\
\text { education }\end{array}$} & $\begin{array}{l}\text { Illiterate/read and } \\
\text { write }\end{array}$ & 15 & 30 & 2 & 4 & 0 & 0 & \multirow{3}{*}{$\begin{array}{l}5.161 \\
.271\end{array}$} & 13 & 26 & 4 & 8 & \multirow{3}{*}{$\begin{array}{l}9.699 \\
.008^{*}\end{array}$} \\
\hline & Secondary education & 22 & 44 & 0 & 0 & 1 & 2 & & 19 & 38 & 4 & 8 & \\
\hline & University education & 10 & 20 & 0 & 0 & 0 & 0 & & 3 & 6 & 7 & 14 & \\
\hline \multirow{2}{*}{ Occupation } & Work & 15 & 30 & 0 & 0 & 1 & 2 & \multirow{2}{*}{$\begin{array}{l}3.066 \\
.216\end{array}$} & 8 & 16 & 8 & 16 & \multirow{2}{*}{$\begin{array}{l}4.482 \\
.034^{*}\end{array}$} \\
\hline & Not work & 32 & 64 & 2 & 4 & 0 & 0 & & 27 & 54 & 7 & 14 & \\
\hline
\end{tabular}

* Significant at $P<.05$

Hemodialysis procedure usually occurs three times a week for at least 3 to 4 hours per day. Caregivers help hemodialysis patients in many daily activities at home, including transportation to the dialysis centers and other places, symptoms management, mobility, dressing, and preparing an appropriate renal diet. Nurses should be trained enough to help caregivers how they manage patients at home. ${ }^{[24]}$ Most of the research has been concentrated and interested on the hemodialysis patients, while their caregivers spouse and part- ners who help in their treatment, and experience losses and potential changes were neglected. ${ }^{[44]}$

The study results revealed that all caregivers obtained severe burden level on assessment pre empowerment intervention. These findings were in accordance with Bayoumi (2014) and Mashayekhi et al. (2015) reported that, caregivers categorize burden as moderate to severe. ${ }^{[44,45]}$ Other research reported that majority of the unpaid caregiver having extremely high 
perception level of burden. ${ }^{[46]}$ Alnazly and Samara (2014) found that, as a result of care giving, caregivers found to be socially isolated, with their health deteriorating, overwhelmed with the responsibility, and having little time for self-care. ${ }^{[47]}$ Given the high level of burden that is associated with care giving to patients receiving hemodialysis such as emotional and physical impacts. Interventions to target those co morbidities as part of hemodialysis care giving are still needed.

Table 9. Relation between socio demographic data and total Burden level score among studied care givers empowerment

\begin{tabular}{|c|c|c|c|c|c|c|c|c|c|c|c|}
\hline \multirow{3}{*}{ Categories } & & \multicolumn{3}{|c|}{ Pre $(n=50)$} & \multicolumn{7}{|c|}{ Post $(n=50)$} \\
\hline & & \multicolumn{2}{|c|}{$\begin{array}{l}61-88 \\
\text { Severe }\end{array}$} & \multirow{2}{*}{$\begin{array}{l}\chi^{2} \\
P\end{array}$} & \multicolumn{2}{|c|}{$\begin{array}{l}0-20 \\
\text { Little }\end{array}$} & \multicolumn{2}{|c|}{$\begin{array}{l}\text { 21- } 40 \\
\text { Mild }\end{array}$} & \multicolumn{2}{|c|}{$\begin{array}{l}41-60 \\
\text { Moderate }\end{array}$} & \multirow{2}{*}{$\begin{array}{l}\chi^{2} \\
P\end{array}$} \\
\hline & & $\mathbf{N}$ & $\%$ & & $\mathbf{N}$ & $\%$ & $\mathbf{N}$ & $\%$ & $\mathbf{N}$ & $\%$ & \\
\hline \multirow[b]{2}{*}{ Age } & $30-40$ years & 26 & 52 & \multirow[b]{2}{*}{ - } & 9 & 18 & 17 & 34 & 0 & 0 & \multirow{2}{*}{$\begin{array}{l}5.883 \\
.053\end{array}$} \\
\hline & 41-65 years & 24 & 48 & & 4 & 8 & 16 & 32 & 4 & 8 & \\
\hline \multirow{2}{*}{ Sex } & Male & 12 & 24 & \multirow{2}{*}{ - } & 4 & 8 & 8 & 16 & 0 & 0 & \multirow{2}{*}{$\begin{array}{l}1.591 \\
.451\end{array}$} \\
\hline & Female & 38 & 76 & & 9 & 18 & 25 & 50 & 4 & 8 & \\
\hline \multirow{2}{*}{ Marital status } & Married & 47 & 94 & \multirow{2}{*}{-} & 12 & 24 & 32 & 64 & 3 & 6 & \multirow{2}{*}{$\begin{array}{l}3.142 \\
0.208\end{array}$} \\
\hline & Widow & 3 & 6 & & 1 & 2 & 1 & 2 & 1 & 2 & \\
\hline \multirow{3}{*}{ Relation degree to patient } & Wife & 28 & 56 & \multirow{3}{*}{-} & 6 & 12 & 21 & 42 & 1 & 2 & \multirow{3}{*}{$\begin{array}{l}9.600 \\
.048^{*}\end{array}$} \\
\hline & Son/daughter & 12 & 24 & & 4 & 8 & 8 & 16 & 0 & 0 & \\
\hline & Mother/father & 10 & 20 & & 3 & 6 & 4 & 8 & 3 & 2 & \\
\hline \multirow{3}{*}{ Level of education } & Illiterate/read and write & 17 & 34 & \multirow{3}{*}{-} & 4 & 8 & 9 & 18 & 4 & 8 & \multirow{3}{*}{$\begin{array}{l}16.730 \\
.002 *\end{array}$} \\
\hline & Secondary education & 23 & 46 & & 3 & 6 & 20 & 40 & 0 & 0 & \\
\hline & University education & 10 & 20 & & 6 & 12 & 4 & 8 & 0 & 0 & \\
\hline \multirow{2}{*}{ Occupation } & Work & 16 & 32 & \multirow[b]{2}{*}{ - } & 7 & 14 & 9 & 18 & 0 & 0 & \multirow{2}{*}{$\begin{array}{l}5.073 \\
.079\end{array}$} \\
\hline & Not work & 36 & 72 & & 6 & 12 & 24 & 48 & 4 & 8 & \\
\hline \multirow{2}{*}{$\begin{array}{l}\text { Duration of responsibility } \\
\text { for patient care and } \\
\text { combination }\end{array}$} & 2-5 years & 16 & 32 & \multirow[b]{2}{*}{-} & 6 & 12 & 7 & 14 & 3 & 6 & \multirow{2}{*}{$\begin{array}{l}19.062 \\
.039 *\end{array}$} \\
\hline & $6-10$ years & 34 & 68 & & 7 & 14 & 26 & 42 & 1 & 2 & \\
\hline
\end{tabular}

* Significant at $P<.05$

The current study reported also a significant improvement in the total mean score of burden level post empowerment intervention. This can be leaded to an increase in confidence on care-related knowledge and apply of active coping strategies significantly. Also conducting exercises help for relaxation and decreasing stress level.

The researchers of this study found difficulties to find other similar studies in their literature review of HD. Most of the family centered empowerment programs for family caregivers' burden level were done on chronic diseases other than chronic renal disease and hemodialysis. Shahram 2014, found that caregiver burden decreased after the intervention up to the end of the program in the intervention group. However, the control group during the same period had substantial increases in their burden scores. They concluded that this program facilitated the humanistic care and increased satisfaction among congestive heart failure (CHF) family caregivers. ${ }^{[48]}$ This result was in accordance with other studies evaluating empowerment family programs for caregivers of schizophrenia and mood disorders ${ }^{[49]}$ multiple sclerosis. ${ }^{[51]}$

In the present study, a significance difference found between caregivers' burden level and their relation degree to the patient, their educational level and the duration that caregivers spent in their patient care. This agrees with Belasco (2002) ${ }^{[51]}$ who emphasized that caregiver burden associated with the relationship between patient and caregiver and their gender. On the other hand the results of the study that was done by Bayoumi (2014) found a negative significant correlation between total burden score of caregivers and their age and educational level. ${ }^{[45]}$ While, Suri et al. (2011) illustrated that there was no significant correlation between perceived caregiver burden and their demographic factors. ${ }^{[46]}$

At the end of our discussion, it can illustrated that hemodialysis affected negatively on physical, psychological, cognitive and social status of the patients and their caregivers and need a comprehensive approach of nursing intervention. Patients 
and their caregivers should be included and encouraged to participate actively in the care process. Empowerment interventions that directed toward increasing knowledge, awareness, motivation, skills and developing self-efficacy, selfesteem and self-control support adopting preventive behaviors and increases self-care self-efficacy of HD patients and their caregivers and relieving burden level upon caregivers.

\section{CONCLUSION AND RECOMMENDATION}

Based on our study findings, we can conclude that presence of person have chronic renal diseases and go on hemodialysis interrupt the entire of the family unit and leave serious effect on patients and their caregivers. Empowerment of hemodialysis patients and their caregivers in hemodialysis department can assist patients and their caregivers with the management of health-related problems of the patients and improve their self efficacy and decrease the burden of their caregivers. So, we can recommend that:

(1) Before the beginning of dialysis therapy, health professionals should identify and explore patient needs and potential caregiver in the family of patient with chronic kidney failure. Empowerment programs should be es- tablished to prepare them for the task to be carried out, mainly in the initial phase of their activities.

(2) Services that provided to hemodialysis patients and their caregivers should respond to their needs at different stages.

(3) Caregivers should be monitored in relation to their burden and depression signs, and, when necessary, interventions should be implemented to offer psychosocial support.

(4) Further researches needed to emphasize the effect of empowerment interventions on relieving burden level upon HD patients and their caregivers.

\section{ACKNOWLEDGements}

At the end of this work we want to offer our great thanks to the director and staff of the dialysis unit in Tanta University for their cooperation and at the same time for all patients and their caregivers for giving their time and understanding our message.

\section{CONFLICTS OF INTEREST DisClOSURE}

The authors declare that there is no conflict of interest statement.

\section{REFERENCES}

[1] Noor ul A, Raja TM, Javaid A, et al. Evaluating Urea and Creatinine Levels in Chronic Renal Failure Pre and Post Dialysis: A Prospective Study. Journal of Cardiovascular Disease. 2014; 2(2): 1-4.

[2] Heidarzadeh S, Jalilazar T. Relationship between quality of life and self-care ability in patients receiving hemodialysis. Iranian Journal of Nursing and Midwifery Research. 2010; 15: 71. PMid:21589783

[3] Pakpour AH, Saffari M, Yekaninejad MS, et al. Health-related quality of life in a sample of iranian patients on hemodialysis. Iran J Kidney Dis. 2010; 4: 50-9. PMid:20081305

[4] El Bahanasy RE, Mahrous OA, Abu Salem ME, et al. The role of microalbuminuria in population screening for chronic kidney disease in an Egyptian village Menufia. Medical Journal Egypt. 2013; 26 (1): $18-22$.

[5] Atashpeikar S, Jalilazar T, Heidarzadeh M. Self-care ability in hemodialysis patients. Journal of Caring Sciences. 2012; 1: 31-35. PMid:25276673

[6] Moattari M, Ebrahimi M, Sharifi N, et al. The effect of empowerment on the self-efficacy, quality of life and clinical and laboratory indicators of patients treated with hemodialysis: A randomized controlled trial. Health and Quality of Life Outcomes. 2012; 10: 1-10. PMid:22992449 http://dx.doi.org/10.1186/1477-752 5-10-115

[7] Ouzouni S, Kouidi E, Sioulis A, et al. Effects of intradialytic exercise training on health related quality of life indices in haemodialysis patients. Clinical Rehabilitation. 2009; 23: 53-63. PMid:19114437 http://dx.doi.org/10.1177/0269215508096760
[8] Moshtagh Z, Naeeni K, Hamzezade M, et al. The effects of nutrition education on mental health of the hemodialysis patients in maragheh, east-azerbaijan, iran. Life Science Journal. 2013; 10.

[9] Tong A, Sainsbury P, Craig JC. Support interventions for caregivers of people with chronic kidney disease: a systematic review. Nephrol Dial Transplant. 2008; 23: 3960-3965. PMid:18658178 http://dx.doi.org/10.1093/ndt/gfn415

[10] Sathvik B, Parthasarathi G, Narahari M, et al. An assessment of the quality of life in hemodialysis patients using the whoqolbref questionnaire. Indian Journal of Nephrology. 2008; 18: 141. PMid:20142925 http://dx.doi.org/10.4103/0971-4065.45 288

[11] Masoud R, Lila M, Mansooreh A, et al. Self-care self-efficacy and quality of life among patients receiving hemodialysis in south-east of iran. Asian J. Nursing Edu. and Research. 2014.

[12] Masoodi R, Alhani F, Rabiei L, et al. The effect of family -centered empowerment model on quality of life and self of mulyiple sclerosis patients family care givers. Iranian Journal of Nursing Research. 2013; 7(27): 32-43.

[13] Ghazavi Z, Minooei MS, Abdeyazdan Z, et al. Effect of family empowerment model on quality of life in children with chronic kidney diseases. Iran J Nurs Midwifery Res. 2014; 19(4): 371-375. PMid:25183977

[14] Ohman M, Soderberg S. The experiences of close relatives living with a person with serious chronic illness. Qual Health Res. 2004; 14(3): 396-410. PMid:15011906 http://dx.doi.org/10.1177 $/ 1049732303261692$

[15] Paulson M, Norberg A, Soderberg S. Living in the shadow of fibromyalgic pain: the meaning of female partners' experiences. J Clin 
Nurs. 2003; 12(2): 235-243. PMid:12603556 http://dx.doi.org /10.1046/j.1365-2702.2003.00733.x

[16] Natterlund B, Ahlstrom G. Experience of social support in rehabilitation: a phenomenological study. J Adv Nurs. 1999; 30(6): 13321340. PMid: 10583643 http://dx.doi.org/10.1046/j.1365-2 648.1999.01211.x

[17] Moattari M, Ebrahimi M, Sharifi N, et al. The effect of empowerment on the self-efficacy, quality of life and clinical and laboratory indicators of patients treated with hemodialysis: a randomized controlled trial. Health and Quality of Life Outcomes. 2012; 10: 115. PMid:22992449 http://dx.doi.org/10.1186/1477-752 5-10-115

[18] Bandura A. Health promotion by social cognitive means. Health Educ Behav. 2004; 31(2): 143-164. PMid:15090118 http://dx.doi.o $\mathrm{rg} / 10.1177 / 1090198104263660$

[19] Chen S, Lewthwaite R, Schweighofer N, et al. Discriminant validity of a new measure of self-efficacy for reaching movements after stroke-induced hemiparesis. Journal of Hand Therapy. 2012. PMid:23123014

[20] Akin S, Can G, Durna Z, et al. Preliminary testing of a turkish version of the strategies used by patients to promote health (supph) scale in a sample of breast cancer patients. Journal of Nursing and Healthcare of Chronic Illness. 2009; 1: 303-310. http://dx.doi.org/10.1111/j.1752-9824.2009.01032.x

[21] Marks R, Allegrante JP, Lorig K. A review and synthesis of research evidence for self-efficacy-enhancing interventions for reducing chronic disability: Implications for health education practice (part 1). Health Promot Pract. 2005; 6(1): 37-43. PMid:15574526 http://dx.doi.org/10.1177/1524839904266790

[22] Marks R, Allegrante J, Lorig K. A review and synthesis of research evidence for self-efficacy-enhancing interventions for reducing chronic disability: implications for health education practice (part II). Health Promotion Practice. 2005; 6: 148-156. PMid:15855284 http://dx.doi.org/10.1177/1524839904266792

[23] Ziegert K, Fridlund B, Lidell E. Time for dialysis as time to live: experiences of time in everyday life of the Swedish next of kin of hemodialysis patients. Nurs Health Sci. 2009; 11(1): 4550. PMid:19298308 http://dx.doi.org/10.1111/j.1442-2 $018.2009 .00429 . x$

[24] Arechabala MC, Catoni MI, Palma E, et al. Depression and selfperceived burden of care by hemodialysis patients and their caregivers. Rev Panam Salud Publica. 2011; 30(1): 74-9. PMid:22159654 http://dx.doi.org/10.1590/S1020-49892011000700011

[25] Lin CC, Wu CC, Anderson RM, et al. The chronic kidney disease self-efficacy (CKD-SE) instrument: development and psychometric evaluation. Nephrol Dial Transplant. 2012; 27: 3828-3834. PMid:22344776 http://dx.doi.org/10.1093/ndt/gfr788

[26] Steffen AM, Christine MK, Zeiss AM, et al. The Revised Scale for Care giving Self efficacy: Reliability and validity studies. The Journals of Gerontology. 2002.

[27] Rankin ED, Haut MW, Keefover RW, et al. The establishment of clinical cutoffs in measuring caregiver burden in dementia. Gerontologist. 1994; 34(6): 828-32. http://dx.doi .org/10.1093/geront/34 .6 .828

[28] Cummings JL, Frank JC, Cherry D, et al. Guidelines for managing Alzheimer's disease: part I. Assessment. Am Fam Physician. 2002; 65(11): 2263-2272. PMid:12074525

[29] Ali HMA, Elsebai NA, RamadanFA, et al. Impact of Teaching Guidelines on Quality of Life for Hemodialysis Patients. Nature and Science. 2011; 9(8): 214-222.

[30] The National Kidney and Urologic Diseases Information Clearinghouse is a service of the National Institute of Diabetes and Digestive and Kidney Diseases, National Institutes of Health. National Kidney and Urologic Diseases Information Clearinghouse. 2014.

[31] Berns JS. Hemodialysis in the older adult . Adv Chronic Kidney Dis 2015; $12(1): 71$.

[32] Coresh J, Astor BC, Greene T, et al. Prevalence of chronic kidney disease and decreased kidney function in the adult US population: Third National Health and Nutrition Examination Survey. Am J Kidney Dis. 2003; 41: 1-12. PMid:12500213 http: //dx.doi.org/10.1053/ajkd.2003.50007

[33] Kurella M, Covinsky KE, Collins AJ, et al. Octogenarians and nonagenarians starting dialysis in the United States. Ann Intern Med 2007; 146: 177-183. http://dx.doi.org/10.7326/0003-481 9-146-3-200702060-00006

[34] Rayyani M, MalekyanL, Forouzi MA, et al. Self-care Self-efficacy and Quality of Life among Patients Receiving Hemodialysis in SouthEast of Iran. Asian J. Nursing Edu and Research. 2014; 4(2): 165-171

[35] El-Sayed MM. Nurses Role in Managing Complications of Patients on Hemodialysis. M.Sc.N Thesis, Faculty of Nursing, Ain Shams University. 2007: 147-148, 154.

[36] Al-Garini RS. Assessment of Health- Related Quality of Life Among End-Stage Renal Disease (ESRD) Adult patients Undergoing Hemodialysis at the Eastern Region. Master Thesis. Collage of Nursing, King Saudi University. 2006.

[37] Doran D. Nursing outcomes: The state of the science, Jones and Bartlett Publishers. 2010.

[38] Royan Zi, Rayyani M, Behnampour N, et al. The effect of empowerment program on empowerment level and self-care self-efficacy of patients on hemodialysis treatment. J Nurs Midwifery Res. 2013 Jan-Feb; 18(1): 84-87.

[39] Berns JS. A survey-based evaluation of self-perceived competency after nephrology fellowship training. Clinical Journal of the American Society of Nephrology. 2010; 5: 490-496. PMid:20089491 http://dx.doi.org/10.2215/CJN.08461109

[40] Weng LC, Dai YT, HuangHL, et al. Self-efficacy, self-care behaviours and quality of life of kidney transplant recipients. Journal of Advanced Nursing. 2010; 66: 828-838. PMid:20423370 http://dx.doi.org/10.1111/j.1365-2648.2009.05243.x

[41] Barbareschi G, Sanderman R, Leegte IL, et al. Educational level and the quality of life of heart failure patients: A longitudinal study. Journal of Cardiac Failure. 2011; 17: 47-53. PMid:21187264 http://dx.doi.org/10.1016/j.cardfail.2010.08.005

[42] Belasco A, Barbosa D, Bettencourt AR, et al. Quality of Life of Family Caregivers of Elderly Patients on Hemodialysis and Peritoneal Dialysis. American Journal of Kidney Diseases. 2006; 48(6): 955-963. PMid:17162150 http://dx.doi.org/10.1053/j.ajk d. 2006.08 .017

[43] Opara JA, Jaracz K. Quality of life of post-stroke patients and their caregivers: Journal of Medicine and Life, Bucharest, Romania. 2010; 58(5): 697-701.

[44] Mashayekhi F, Pilevarzadeh M, Rafati F. The Assessment of Caregiver Burden in Caregivers oh Hemodialysis Patients Mater. Sociomed. 2015; 27(5): 333-336. PMid:26622201 http://dx.doi.o $\mathrm{rg} / 10.5455 / \mathrm{msm} \cdot 2015 \cdot 27.333-336$

[45] Bayoumi MM. Subjective Burden on Family Carers of Hemodialysis Patients.Open Journal of Nephrology. 2014; 4: 79-85. http: //dx.doi.org/10.4236/ojneph.2014.42011

[46] Suri RS, Larive B, Garg AX, et al. Burden on Caregivers as Perceived by Hemodialysis Patients in the Frequent Hemodialysis Network (FHN) Trials. Nephrology Dialysis Transplantation. 2011; 26: 2316-2322. http://dx.doi.org/10.1093/ndt/gfr007 
[47] Alnazly EK, Samara NA. The Burdens on Caregivers of Patients above 65 Years Old Receiving Hemodialysis: A Qualitative Study. Health Care Current Reviews. 2014.

[48] Shahram E, Masoud B, Mohsen S, et al. The effectiveness of a supportive educative group intervention on family caregiver burden of patients with heart failure. Iran J Nurs Midwifery Res. 2014 May-Jun; 19(3): 217-223.

[49] Navidian A, Kerman SF, Navabi RS. The effectiveness of a group psycho-educational program on family caregiver burden of patients with mental disorders. BMC Res Notes. 2012; 5:
399. PMid:22853873 http://dx.doi.org/10.1186/1756-050 0-5-399

[50] Masoodi R, Alhani F, Moghadassi J, et al. The effect of familycentered empowerment model on skill, attitude, and knowledge of multiple sclerosis caregivers. J Birjand Med Univ Med Sci. 2010; 17: 87-97.

[51] Belasco AG, Sesso R. Burden and Quality of Life of Caregivers for Hemodialysis Patients. American Journal of Kidney Diseases. 2002; 39: 805-812. http://dx.doi.org/10.1053/ajkd.2002.32001 